\title{
Natural, Cultural and Industrial Heritage as a Basis for Sustainable Regional Development within the Geopark Idrija Project [Slovenia]
}

\author{
Gorjup-Kavčič Mojca ${ }^{A *}$, Režun Bojan ${ }^{B}$, Eržen UrošB, Peljhan Martina ${ }^{B}$, Mulec Ivo ${ }^{C}$ \\ Received: November 2010 | Revised: December 2010 | Accepted: December 2010
}

\begin{abstract}
The Idrija Municipality, situated in the western part of Slovenia, extends over an area of $294 \mathrm{~km}^{2}$ with around 12,000 inhabitants. The area of Idrija is placed at the crossing of Dinaric and Alpine mountain ranges. This position is the reason for an exceptionally diverse surface with deep gorges, high Karst tablelands and mountain tops. Furthermore, the most important natural feature is Idrija mercury ore deposit which was exploited by the Idrija Mercury Mine Ltd. and was the leading force in the development of the region through centuries. Today, the mine is closed but it left an outstanding cultural and industrial heritage that needs to be conserved for future generations - local people to sustain their identity and for visitors.

To present the richness of Idrija region the local authorities have put many efforts into establishment of the Geopark since 2007. In 2009 concrete steps were taken with the inventory, thematic trails, evaluation of geoheritage, educational programs, research thesis, etc. With this project the basis and guidelines for the establishment of the Geopark were set. In 2010, the activities have continued at the Municipality level by setting an organisation structure of the future Geopark.
\end{abstract}

Keywords: natural heritage, industrial heritage, sustainable development, Geopark Idrija

\section{Introduction}

In one of its many definitions sustainable development is understood as development that meets the needs of the present without compromising the ability of the future generations to "meet their own needs" (United nations, 1987). This can be achieved by a stable relationship between the human activities and environment and not diminishing the prospects for future generations to enjoy the quality of live at least as good as our own (http://webcache.googleusercontent.com/ search?q=cache:oRGF--ocPgsJ:www.gdrc.org/ sustdev/definitions.html+sustainable+developme $n t+$ definition\&cd=2\&hl=sl\&ct=clnk\&gl=si).

In tourism changes have been recognised connected to the principle of sustainable development. The concept of "niche tourism" has emerged in couter-point to what is commonly referred to as "mass tourism", which has negative impacts in relation to environmental degradation and socio-cultural disturbance. For managers and planers seeking to utilise tourism as a mechanism for economic development it offers greater opportunities and a tourism that is more sustainable, less damaging and, importantly, more capable of delivering high-spending tourists. For tourists, niche tourism appears to offer a more meaningful set of experiences in the knowledge that their needs in wants are being met (Robinson \& Novelli, 2005).

Since I990's the concept of geotourism has been developed and promoted, which is a developing form of niche tourism - special interest tourism, which is focusing on geology and the formation of landscapes (Hose, I995, 2005). Another definition of geotourism, as a sustainable tourism with a primary focus on experiencing the earth's geo-

\footnotetext{
A Idrija Municipality, Mestni trg 1, 5280 Idrija, Slovenia

B Idrija Mercury Mine Ltd., Bazoviška 2, 5280 Idrija, Slovenia

c Department of Geography, Tourism and Hotel Management, Faculty of Science, University of Novi Sad, Serbia

* Corresponding author: Gorjup-Kavčič Mojca, e-mail: mojca.kavcic@idrija.si
} 
logical features in a way that fosters environmental and cultural understanding, appreciation and conservation, and is locally beneficial, was given by Dowling \& Newsome (2006). Whichever way it is defined or described, the "geo" part in geo tourism means geology and geomorphology.

Idrija region represents rich natural heritage with particular parts of outstanding value. Within natural heritage geological heritage has a special place with its mercury ore deposit, cross-sections, Wild Lake, Idrija Fault, Habečkovo brezno shaft, etc. All together with agitated landforms it offers a great potential for development of geotourism and implementation of new trends in tourism also in Idrija region.

Because of the Idrija Mercury Mine that constantly improved the excavation processes and techniques Idrija also has a potential for improvement and development of industrial tourism. The research and tourism of mines, quarries and other kinds of industrial installations gained on importance in late 9o's (Edwards et al., I996). The mines are closed down and the new economic alternatives are extremely important (Ballesteros \& Ramirez, 2007). At the same time, the threat of the dissolution of local society, increases interest in heritage, in identity, and the search for a symbolic redefinition of the community that could sustain the continuity of local mining societies (Cohen, I985: Dicks, 2000; Etiembre et al. 1999; Escalera et al., I995, Ruiz, I999, 2002, cf. Ballesteros \& Ramires, 2007). In this context the development of heritage tourism is understood not only as one of the pillars of alternative economic and social development to replace the deactivated mining industry, but also an active agent in the process of defining the diverse collective identities (Ballesteros \& Ramirez, 2007).

The history of Idrija has been inseparably connected to Idrija Mercury Mine, starting in 1490 when mercury was first discovered by a tubemaker. After a discovery the mine was growing underground together with the town above, reaching the peak of excavating and extracting of mercury in the beginning of 20 th century with 820 tonns of extracted mercury (Mohorič, I960). In the second half of the igth century the Idrija Mine was one of the best equipped mines in Austro-Hungarian monarchy. It constantly improved the processes of extracting the cinnabar ore. To preserve the identity of the area is extremely important to conserve the tangible and intangible heritage, which was left after five hundred years of mining. After all, all these technological achievements did not remain in this area, but have spread in other mining towns in Europe and across the Ocean to South America where they used mercury for amalgamation process and this way had the impact on the development of the whole world.

After the decision of shutting down the mine the industry undergone complete restructuring and the town of Idrija became the development centre for electric-processing and high technology industry. The name of Idrija is once again returning to the world with great success. And most important, no economic and social crisis appeared after the Mine shut down.

\section{Establishing Geopark Idrija}

With its natural and industrial heritage Idrija region represents one of the most valuable and interesting areas in Slovenia. In the past separate parts of the heritage were managed and offered to visitors separately. This often caused organisational problems and dissatisfaction between tourist managers and often doubled the work. Some of the tourist offers were not promoted adequately to other bigger offers and thus left to themselves to survive in this big and demanding market. It was clearly shown that tourist offers need to be coordinated and promoted equally and offering programmes to all kind of visitors and tourist. This was not only thought by tourist managers but also initiatives from the countryside started to come to the local authorities, expressing the need for better and coordinated management and joining tourist offers, education institutions, local people, companies into one organisational form. In the organisational form of Geopark all the characteristics and needs for integral sustainable management of the area were joined. The initiative for establishing the Geopark Idrija begun in 2007 with the setting up the initiative group which coordinated activities in order to prepare basis for further work. Also the decision was made about the territory which in the time of establishment and setting is the area of Idrija Municipality. In the EGN charter (http:// www.europeangeoparks.org/isite/page/8, I, o. asp?mu $=4 \& \mathrm{cmu}=26 \&$ thID $=0$ ) is indicated that the geopark must include a particular geological heritage of particular importance, furthermore there can be interest also for archaeological, ecological, historical or cultural heritage. Our goal is to embrace the entire outstanding heritage of Idrija with an integral view and present it to a wide spectrum of visitors, with a special interest in specific tourism places and local products. Furthermore activities are not meant to develop towards "mass tourism" but groups of visitors (for example scholar groups, societies, experts, etc.) with environmental and cultural interest and experiencing characteristics of the area authentically among local people and on the field. This way the 


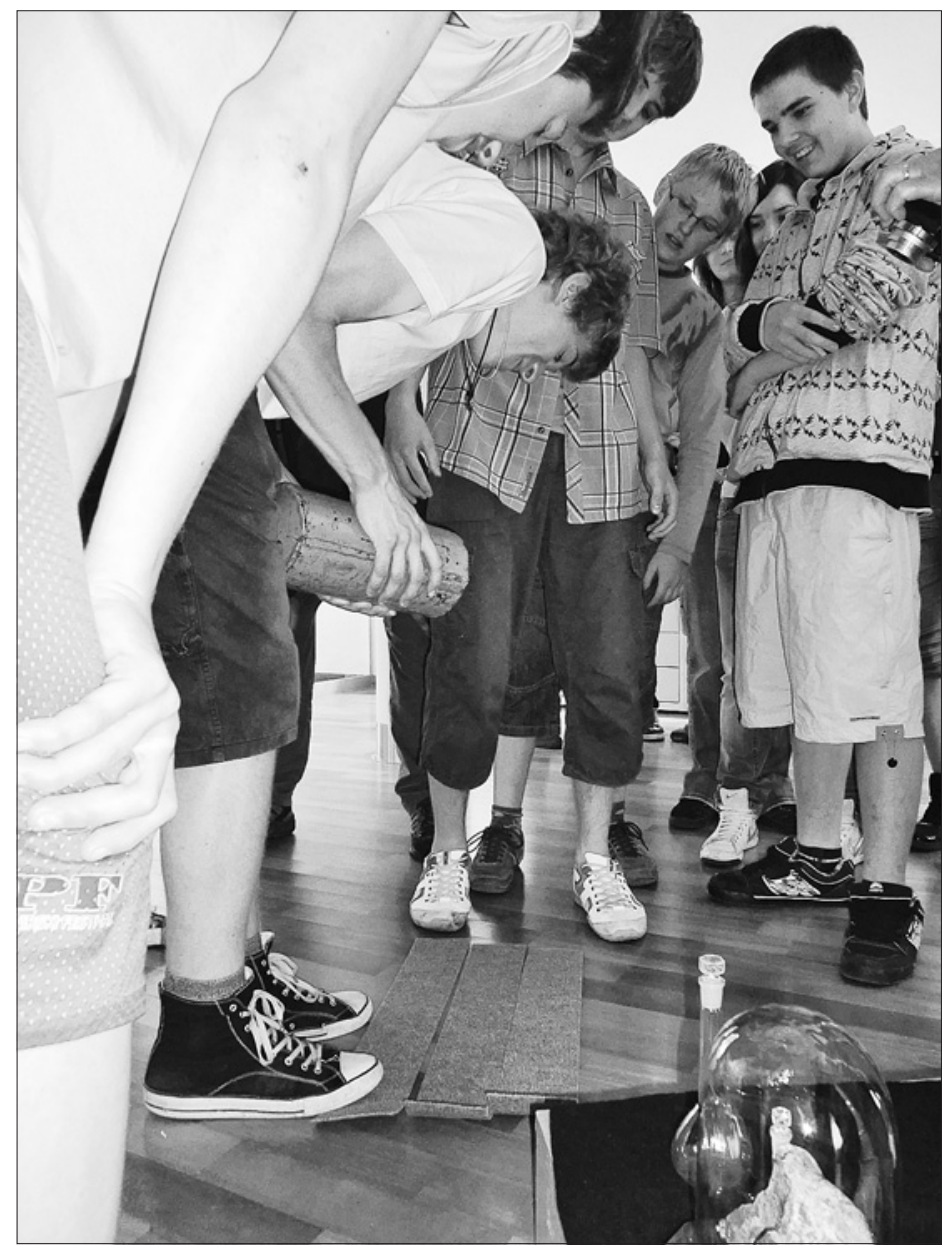

Figure 1. Scholars from Primary School Idrija visited geological collection at the Idrija Mercury Mine Ltd. Administrative building [Author: Bojan Režun] organisation of geopark would also have an active role in the economic development of its territory by development of geotourism and enhancement of a general image linked to the geological heritage (http://www.europeangeoparks.org/isite/ page $/ 8, \mathrm{I}, 0 . \mathrm{asp} ? \mathrm{mu}=4 \& \mathrm{cmu}=26 \& \mathrm{th} \mathrm{ID}=0$ ), which has already been set with a chosen logo by tender. Idrija Municipality and its partners are in the middle of setting organisational structure of aspiring Geopark Idrija. It needs to be stressed that many activities have already been carried out; especially educational activities where some programmes have been on trial in cooperation with local schools, secondary schools, universities and societies (Figure I). A lot of emphasis has also been put into protection and conservation of heritage, starting in 1986 with a decree when many cultural, historical monuments and natural sites were proclaimed. Since 1986 conservation of natural and cultural heritage is carried out by several decrees. The aim of establishing Geopark Idrija is to manage activities in the area in consideration of existing acts and regulations and not to legislate new ones.

Although we know this is the beginning of the long way towards solid structure of Geopark Idrija, but all aspirations for integrated activities coordinated by one organisation have been accepted positively. Recently the main task of geopark project staff is concentrated into raising public awareness about geopark project trying to activate local residents to see the opportunity and raise their interest in participating.

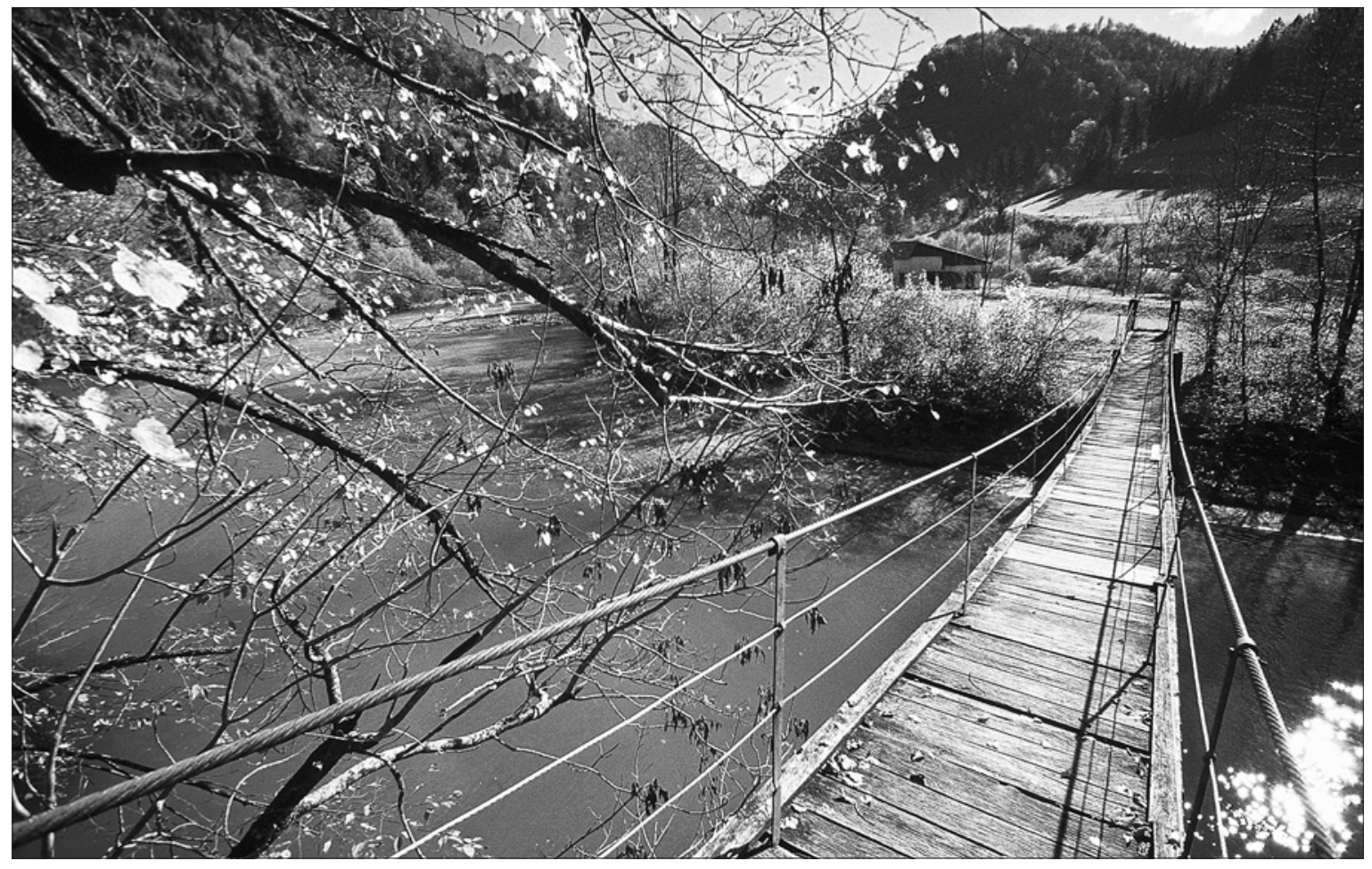

Figure 2. Idrijca River with a suspension bridge [Author: Jože Hanc] 


\section{The outstanding heritage in Idrija region}

Already at first sight a visitor sees that Idrija's region is distinctly marked by the typically diverse surface on the junction of Dinaric and Alpine Mountain Range and represents a lively and picturesque transition between subalpine and karst landscapes. Furthermore is special by the Idrijca River (Figure 2) and its tributaries, which cut deep gorges and uncovered stratigraphic cross-sections, mineral and fossil deposits. Water is also important factor in creating Karst features in carbonate rocks. In a relatively small area a visitor has the opportunity to observe the rocks forming the terrain of Idrija - from oldest Carboniferous to the youngest Paleocene-Eocene rocks. The area has a typical thrust structure due to the far-reaching consequences of the Tertiary tectonic activity (Placer I98I, I999; Vrabec \& Fodor, 2006).

The most important natural feature with no doubt is Idrija mercury ore deposit, unique in the world scale. It is approximately $1500 \mathrm{~m}$ long, 300$600 \mathrm{~m}$ wide, and $450 \mathrm{~m}$ deep, and extends from NW to SE right below the town of Idrija. About $700 \mathrm{~km}$ of shafts were dug out on fifteen levels. I5 8 ore bodies were found in the mine, of which I4I were mineralised with cinnabar - I4 ore bodies with mostly syngenetic mineralisation (Figure 3) and I27 with mostly or only ore of epigenetic origin (Figure 4). Native mercury (Figure 5) is predominant in the remaining I7 ore bodies (Herlec et al., 2006).

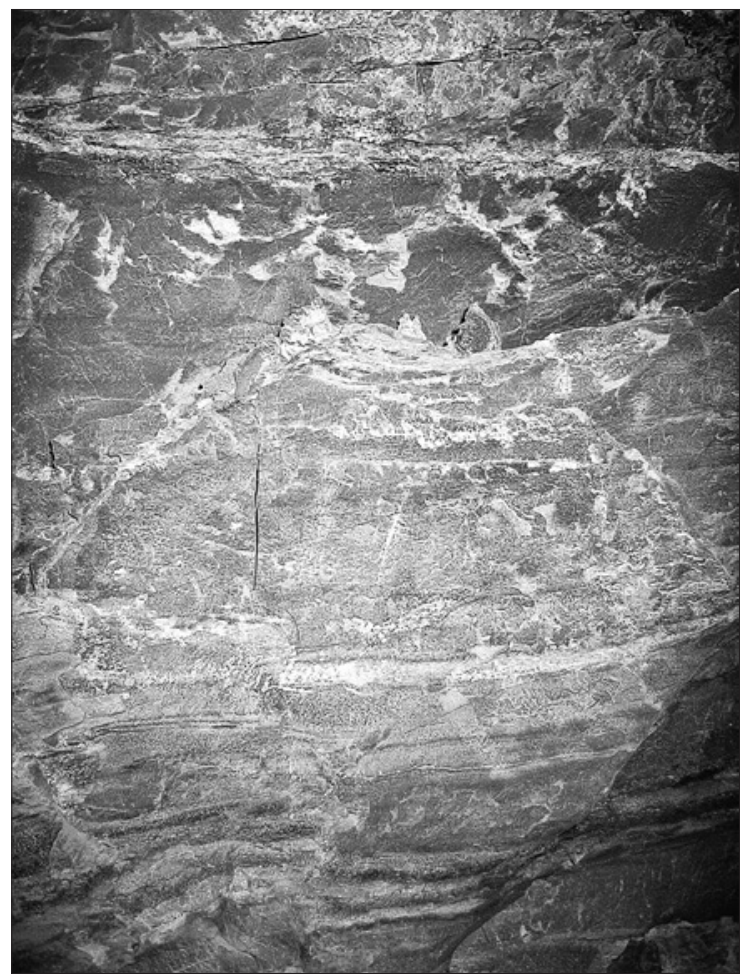

Figure 3. Syngenetic mineralisation with cinnabar [Author: Uroš Eržen]

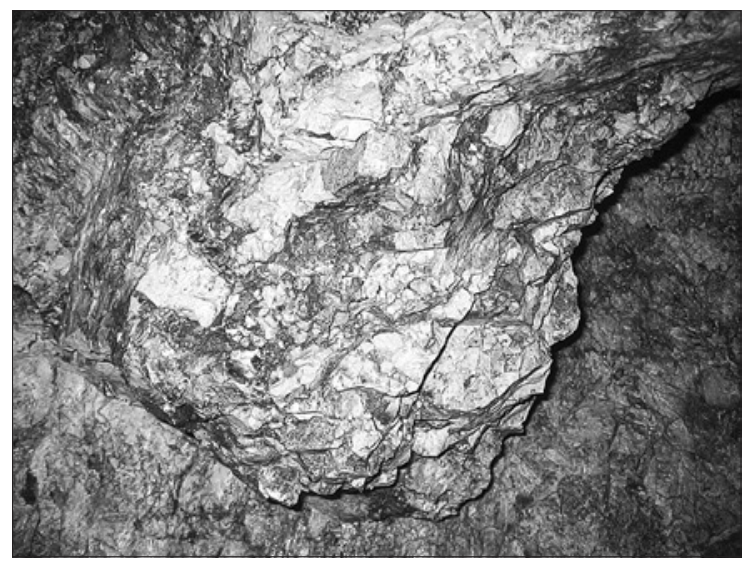

Figure 4. Epigenetic mineralisation with cinnabar in dolomite [Author: Martina Stupar]

Producing I3\% of work's mercury output, the Idrija Mine was, by its quantity of extracted mercury, the second largest mercury mine in the world, the first being Almadén in Spain. Since the adoption of a decision on the mine's shutdown in I988, the mining history is gradually coming to a close. However, some parts of the mine will remain accessible, as it will be necessary to carry out constant supervision, monitoring and servicing of devices. Part of the ore deposit is conserved as geological natural site of national importance, namely two sites, i.e. Anthony's Main Road (Figure 6) with seven geological cross-sections and the $I d-$ rija ore deposit with ten geological cross-sections (Stupar et al., 2005). The Anthony's Main Road has been opened for visitors already in 1994 as a

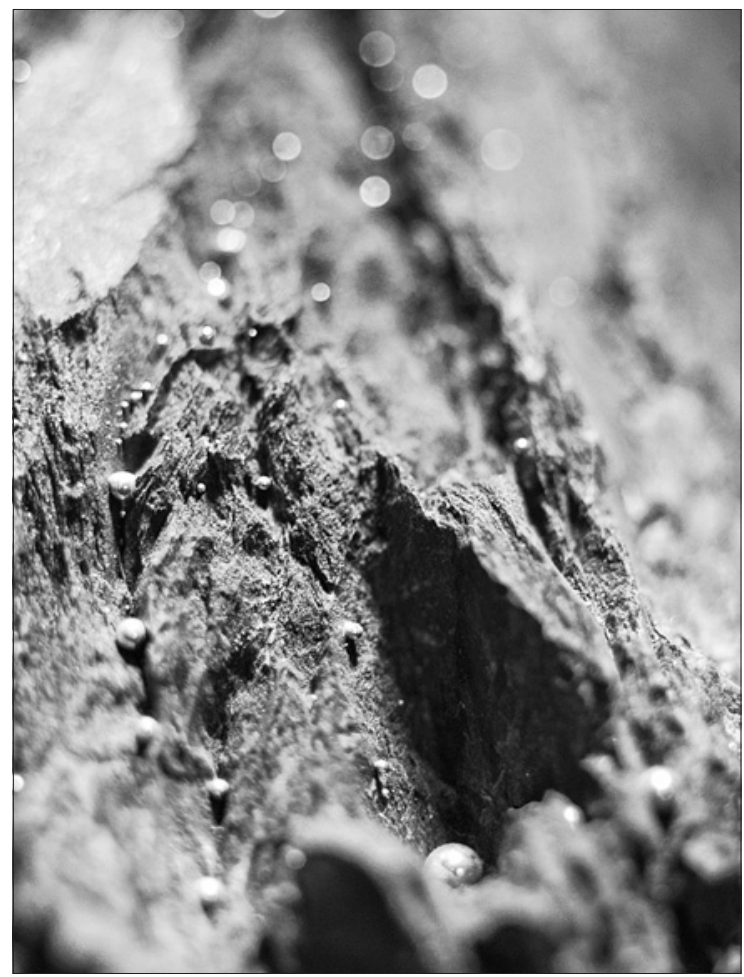

Figure 5. Native mercury in carboniferous shales [Author: Robert Zabukovec] 


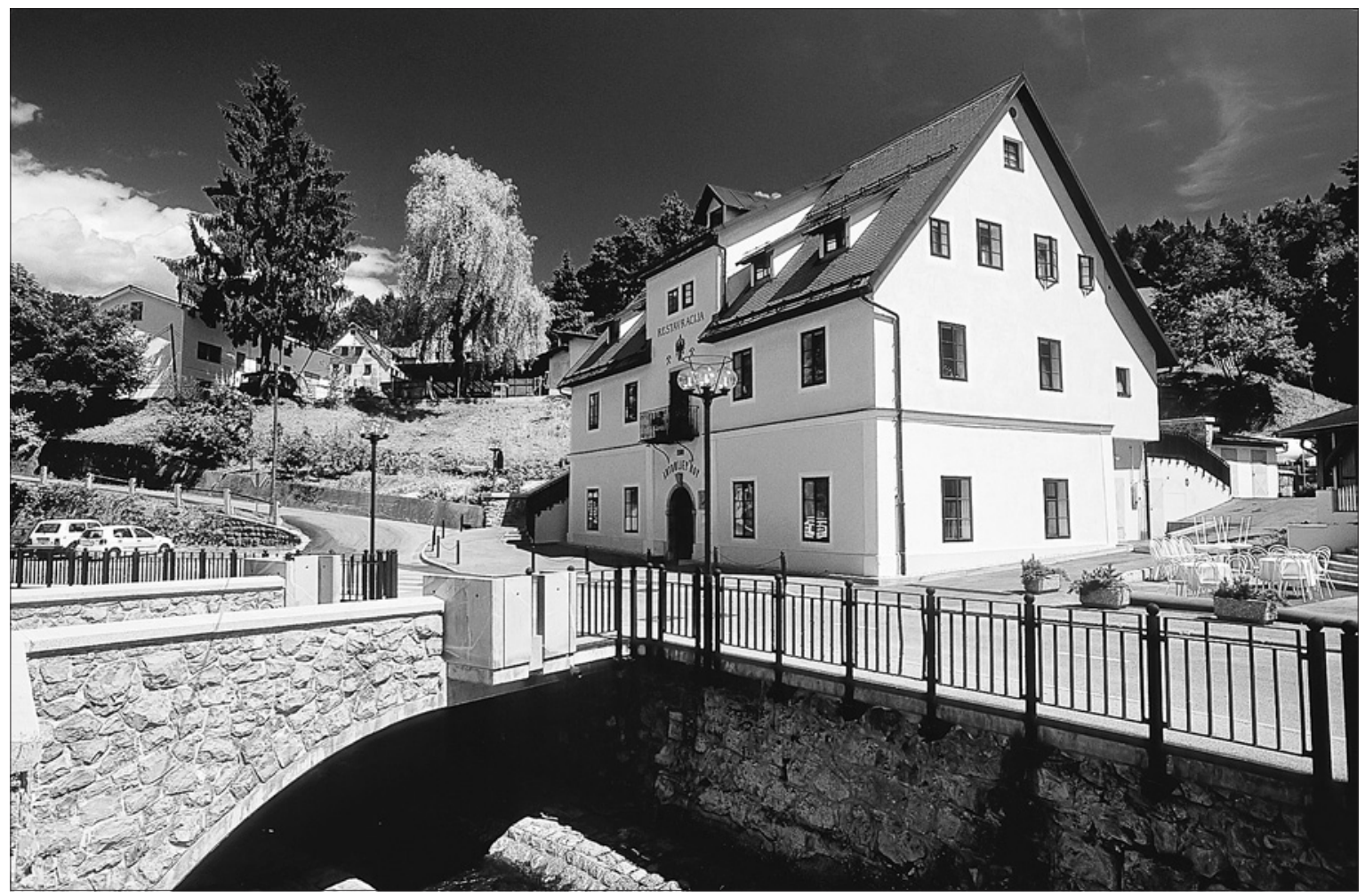

Figure 6. Šelštev - entrance building to the Mine Museum [Author: Matevž Lenarčič]

first Slovenian tourist mine and will be described later in the article.

Over the centuries, various shafts were used by miners to enter and exit the mine, as well as to transport ore from the pit. Francis's shaft (I792) is today one of the oldest preserved mine facilities and one of the most important shafts for the mine's operation and will continue to use also after the mines shutdown. In the building of Francis's shaft the machines, devices and power generators, which were in different time periods located at various work places and sites in the mine, are conserved. Preserved in the yard in front of Francis's shaft are some parts of the Kley pump, dating from 1893 that was used to pump pit water for more than fifty years. According to available data, the Kley pump from Idrija is the only of its kind that is preserved in the world today. For visitors guided tours to the Francis's shaft are arranged by Idrija Municipal Museum.

One of the most important buildings in Idrija is the smelting plant, which has been developing over five centuries from washing native mercury from carboniferous rocks and later up to i8th century a simple burning ore in piles to modern rotary furnaces (Figure 7) that were installed in 1961, 1964 and 1968 and which were in operation all until 1995. The area encompassing the smelting plant of the Idrija Mercury Mine includes the final ropeway station, the separation plant with crusher, a bridge with a conveyor belt, the collection bunker with a feeder system, the rotary furnace, the condenser and a smokestack and accompanying ducts (Eržen U., 2007; Dossier, 2008). From three installed rotary furnace only one is preserved and thus unique in Slovenia. The peak of smelting technology in Idrija was reached with the installation of original Čermak-Špirek's furnace (Figure 8), designed in 1886 by mine employees Josip Čermak and Vincenc Špirek. One of these furnaces (Šermak-Špirek's furnace II from I888), which was in use until I974 (Eržen \& Zelenc, 2008), has been preserved and is believed by industrial archaeologists to be the only of its kind left in the world. It is important because it is a product of local know-how and a technological marvel, resulting in taking a leader position among producers of mercury in the World at the time. Its technical characteristics made the Čermak-Špirek's furnace the most advanced smelting furnace of its time (Eržen, 2007; Dossier, 2008).

The area and building of the smelting plant are planned to reconstruct and to present original furnaces for visitors. In the building of separation the process of extracting the mercury from cinnabar ore will be presented. In the same building the Information and research centre for mercury will be placed and will serve for different groups (scholars, students, tourists, etc). The Centre will inform and educate about the processes of extracting the mercury from ore, ecology, archives and activities for scholars (house of experiments).

The predicament by the huge need for wood was overcome by constrction of water barriers, 


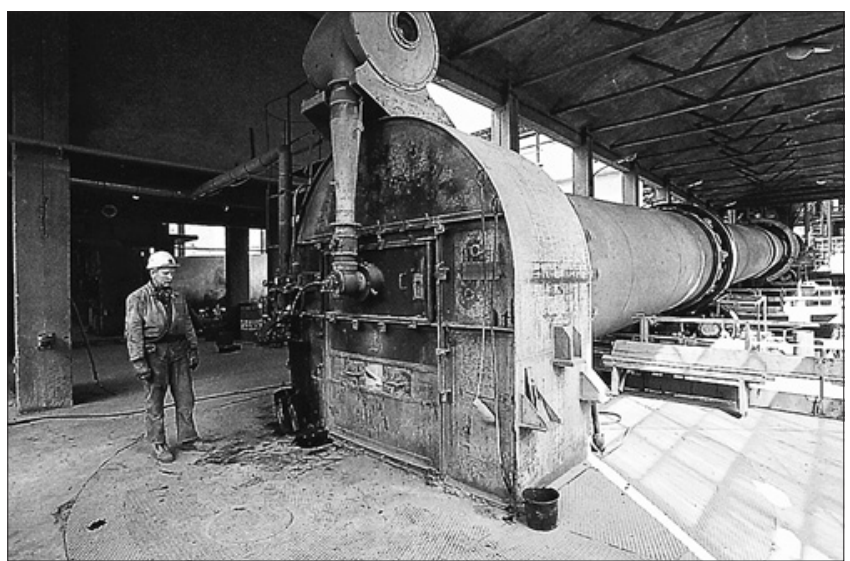

Figure 7. Rotary furnace at the final ore smelting in 1995 [Author: Bogdan Kladnik]

so called Klavže (Figure 9) in I7th century (Zelenc, 2007; Dossier, 2008). The dams had a special opening that was closed with a large door, which allowed water to build up. When enough water accumulated and enough wood had been floated, the door was opened to allow the water to carry the wood in front of the dams to Idrija (up to $30 \mathrm{~km}$ away) where it was stopped by special rake

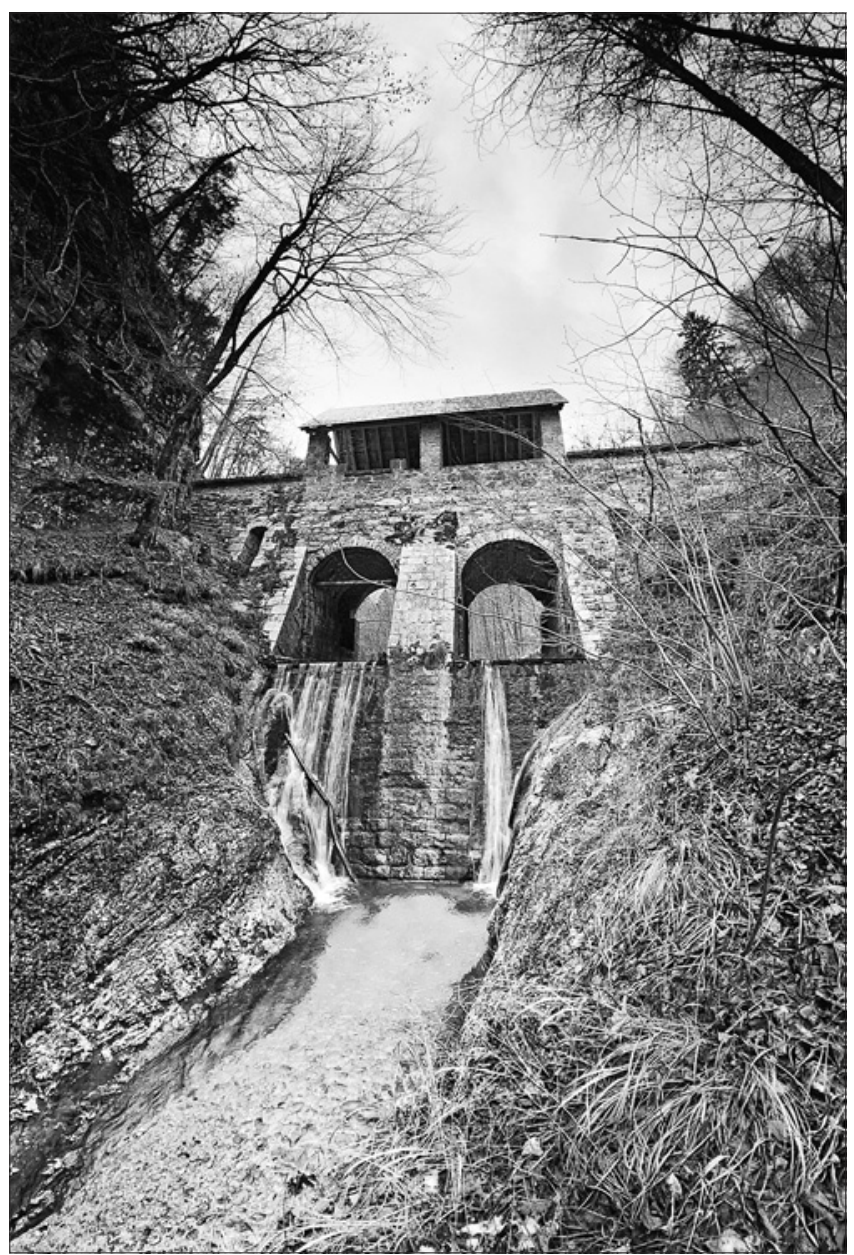

Figure 9. Klavže water barriers on Idrijca River [Author: Robert Zabukovec]

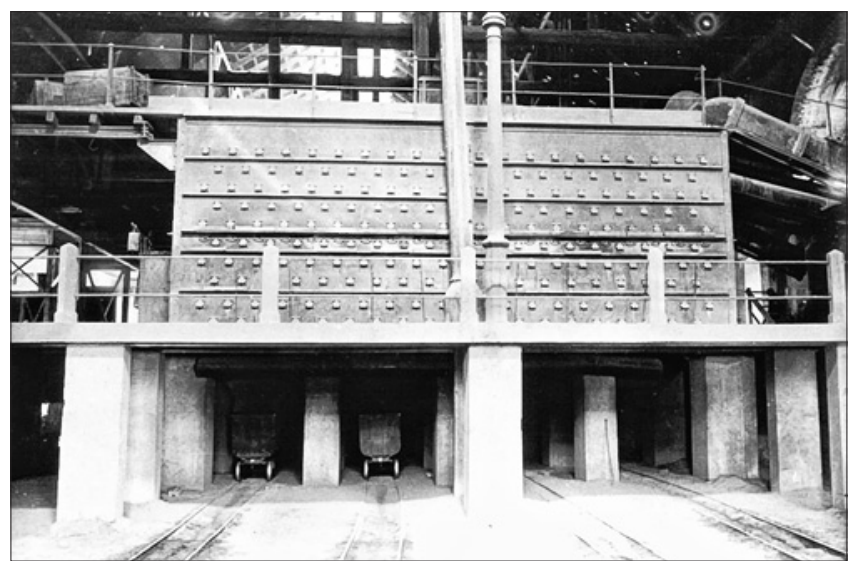

Figure 8. Čermak-Špirek's furnace [Archive of Idrija Mercury Mine Ltd.] mechanism. Today four water barriers, also called "Slovenian pyramids" are preserved and can be admired in whole beauty.

For enourmous energy need the driving force of water was initially used. For this purpose Idrijca River was dammed up at the end of I6th century and a $3.5 \mathrm{~km}$-long water channel Rake was built. The water from channel was used to drive various

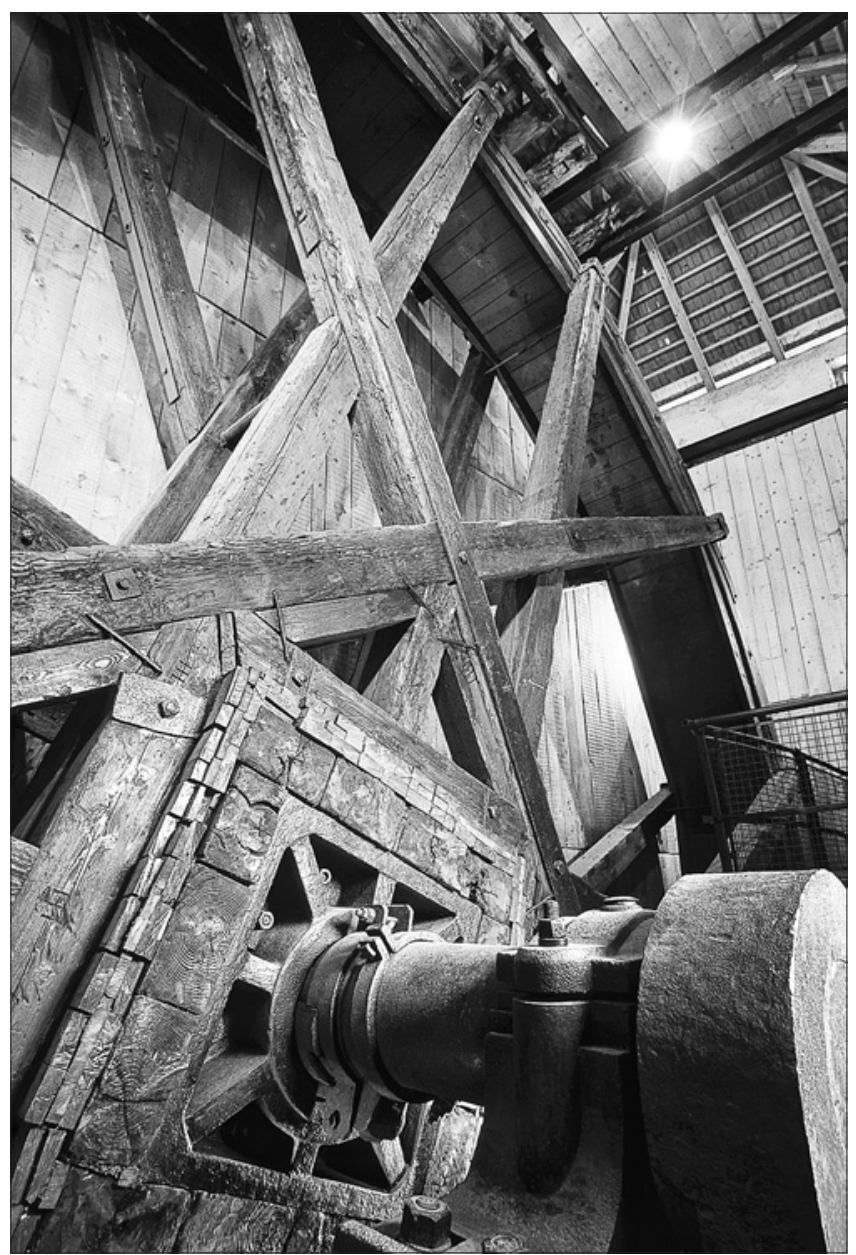

Figure 10. Kamšt - water wheel [Author: Matevž Lenarčič] 
water wheels in order to raise or lower loads into the mine and pump water from the pit. In I79o a huge Kamšt was constructed - a pump featuring the largest preserved wooden wheel (Figure Io) in Europe with a diameter of $13.6 \mathrm{~m}$. For as many as I6o years, this wooden wheel was used to drive a pump that provided approx. 300 litres of water per minute from a depth of $283 \mathrm{~m}$ (Dossier, 2008).

\section{Conserved heritage in Idrija region, arranged and opened for public visit}

Idrija is Slovenia's oldest mining town. The locals used to say: "The town is a mine, the mine is a town" (Leskovec, 2009). The town was growing along with the development and expansion of the mine in the underground. Buildings and streets nowadays tell us the stories of the development, the ups and downs, about the people who lived and worked in the town during the decades and centuries, about their attitude towards the environment, the culture, the education etc. The historical town centre, a protected cultural monument involves the majority of the buildings, important for the mine and the town. They are all connected to mining and the lives of the miners of Idrija. The mine, in state property since 1575, was filling the Habsburg monarchy budget abundantly and at the same time they always provided novelties in production processes as well as modernisation of the working equipment. The miners themselves invented several working methods, machines, devices etc. Many of them have been preserved till the present times, some of them are exceptional for their age, and others for their dimensions, among them there are unique or at least very rare ones. Some of them are already available for the tourists, some of them are waiting for reconstruction.

With the refurbishment of Šelštev and Anthony's Main Road on 22 June I994, i.e. on St. Acacius' day, the oldest part of the mine was opened to the public. This was the first mine arranged for the visitors in Slovenia. Anthony's Main Road is the oldest part of the Idrija Mine and represents one of the oldest preserved entrances into any mine throughout the world, being excavated only a decade after the initial discovery of mercury. For almost half a millennium, miners descended into the pit and returned from their daily labour precisely along this $300 \mathrm{~m}$ long gallery. Nowadays these 500 year old galleries demonstrate the old ways of mining: manual digging and loading and transport of the ore in carts. Pictorial presentations demonstrate the hard work once carried out by the miners. The lower, new level presents mechanical digging, drilling, blasting and loading of the ore. One peculiarity that cannot be found an- ywhere else in the world, are the drops of native mercury in such amount that trickle, tear-like, from the black shale.

About 17.000 visitors come each year to see the multimedia presentations showing mining through the centuries and the underground St. Acacius level. During the last few years our main visitors have been school groups (42\%), other organised groups (23\%) and individual visitors (35\%). The large majority of visitors come from various parts of Slovenia, although around a quarter come from foreign countries.

For tourists two geological collections are arranged in the town of Idrija. The first is situated in the administration building of the Idrija Mercury Mine and the second in the Idrija Municipal Museum. The history of these collections dates to the I8th century, when employees of the Mine were already collecting Idrija's minerals and ores.

The collection in the bulding of Idrija Mercury Mine was set up after the foundation of the geological department within the company. This collection encompasses more than 800 samples and is without any doubt the most extensive collection of Idrija's ore deposit. Due to the complexity and diversity of the Idrija mercury ore deposit and its surroundings, the collection is divided into seven thematic sections. The samples represent individual geological elements classified according to the development and structure of the ore deposit (mineralogy, petrology, sedimentology, mineral geology and tectonics). The collection was officially opened on $22^{\text {nd }}$ June 2008 , the local festive day of St. Acacius. At present only group visits are possible, but in the future we plan to open the collection to daily visitors. During the past year the collection was presented to various groups of visitors, including a group of geologists from the Geological Survey of Slovenia, the Museum Society, a group of students from the University of Ljubljana, Faculty of Natural Sciences and Technology - Geological Department and various school groups.

The second, comprehensive stratigraphical-litological, paleontological and mining collection, was set up by mining experts in 1956 in the Idrija Municipal Museum in Gewerkenegg castle. The castle was built in I6th century and used to serve as the headquarters of the mine administration and as a storehouse for mercury. Today, the castle houses Idrija Municipal Museum. This collection encompasses the part of examples from famous Idrija's natural scientists that collected samples from $18^{\text {th }}$ century on. In the following decades after opening the collection was completed, restored in 1992 and now contains 2,680 registered samples (Režun \& Eržen 2004). In the Museum also the permanent collection "Five Centuries of the Mercury Mine and 
the Town of Idrija" is available. The exhibited documents, maps, photos and original specimens vividly illustrate the town's mining activities through history. Also the Kamšt and machines, devices and power generators, exhibited on Francis's shaft, are managed by the Municipal Museum, where they also arrange guided tours for visitors. Yearly around 2I.00o visitors come to see the collections managed by Municipal Museum in Idrija region. Visitors mostly come in organized groups $(63$ $\%)$, the rest are individuals (37\%). The three quarters of visitors come from Slovenia and around one quarter from foreign visitors.

For general public the trail "Along the rake Following the Trail of Idrija's Natural Scientists" was created with In natural sites and a brochure was published. The trail follows the $2,5 \mathrm{~km}$ of water channel Rake which is connecting the Kamšt and the dam on Idrijca river. The trail was prepared in cooperation with the Idrija Mercury Mine, the Municipality of Idrija, Idrija Municipal Museum and the Tourist Information Centre Idrija. The brochure was published and sites were marked by "scouts". Prior arrangement guided tours can be organised.

\section{Conclusions}

Nature and technological development have always been connected in Idrija region, which today represents a special region in Europe. It is most famous for its Mercury Mine, telling us the story of 500 years long history of mining and development of the region. For many centuries the residents of Idrija and local authorities have been aware of the value of the heritage, which was left after mining. This is also the reason that many activities have been carried out in order to conserve natural heritage and conserve and restore industrial heritage, which today is possible to see in Anthony's Main Road and during guided tours of Idrija Municipal Museum. However duty of authorities and tourist offers today is to conserve and to promote the heritage to conserve the characteristics of cultural region and identity of the area. Especially this is important since the unemployment in the area is rather low, namely $2,2 \%$ in 2008 (http://www. stat.si/obcinevstevilkah/Vsebina.aspx?id=52\#) and the tourism is not the main source for living. Lots of work has been done on conservation of the heritage and the majority is available for public visits. Despite all the efforts in the past, the offer must be modernised and connected into one product, which would be concurrent on the market. Within the project of establishing Idrija Geopark, we would mostly like to offer educational tourism for different groups, to enrich already existing cycling, hiking trails and promote connec- tion between humans and nature. It is important that we present this region with the most known particularity and this is concluded to be the mercury ore deposit. Anyway, within establishing geopark in the whole municipality (also rural areas), other important naturalistic themes and natural heritage will be included as well as cultural landscape, etnology, history, etc.

The establishment of Geopark offers an opportunity to embrace the whole heritage, the opportunity to to join the tourist offers in the region (museums, collections, accommodation offers, restaurants and others) with visitors (school groups, individuals, families, students, scientists, etc.). Aspiring Geopark Idrija after all offers many opportunities for promotion, the recognition among experts from different scientific fields and thus many opportunities for international cooperation.

\section{Acknowledgements}

This paper is a result of I-year project LAS 2010 (Local activity group 20I0): Geological trails - introduction of natural heritage, cofinanced by Leader funds. Authors are grateful to Idrija Municipal Museum, that kindly offered statistical data and anonymous referee for the constructive comments that have contributed to improve the manuscript.

\section{References}

Ballesteros, E.R., Ramirez, M.H. 2007. Identity and community - Reflections on the development of mining heritage tourism in Southern Spain. Tourism Management 28, 677-687.

Dossier, 2008. The Mercury and Silver Binomial On the Intercontinental Camino Real. Almadén, Idrija \& San Luis Potosí. Ministry of Culture of Spain, Republic of Slovenia Ministry of Culture, Permanent Delegation of Mexico to UNESCO, $405 \mathrm{pp}$.

Dowling, R., Newsome, D. 2006. Geotourismsustainability, impacts and management. Elsevier Ltd, Oxford, UK, 260 pp.

Edwards, J.A., Llurdes, I., Coit, J.C. I996. Mines and quarries: Industrial Heritage Tourism. Annals of Tourism Research 23, 2, 34I-363.

Eržen, U. 2007. Območja žgalnic in postopki pridobivanja živega srebra v Idriji: gradivo za pripravo nominacije, Idrija, Slovenia. (unpublished)

Eržen, U., Zelenc, A. 2008. Idrija - Čermak Špirekova peč 2 - Konservatorsko - restavracijski projekt. Rudnik živega srebra Idrija, $34 \mathrm{pp}$. (unpublished)

Herlec, U., Režun, B., Rečnik A., Poljanec F. 2006. Rudišče živega srebra v Idriji. In Scopolia. Glasi- 
lo Prirodoslovnega muzeja Slovenije, Suppl. 3, Prirodoslovni muzej Slovenije in Zavod RS za varstvo narave, Ljubljana, Slovenija, I5-3i.

Hose, T.A. I995. Selling the Story of Britain's Stone, Environmental Interpretation I0, 2, I6-I7.

Hose, T.A. 2005. Geo-Tourism - Appreciating the deep side of landscapes In Novelli, M. (ed.) Niche Tourism; contemporary issues, trends and cases, Elsevier Science Ltd., Oxford, UK, 27-37.

http://webcache.googleusercontent.com/ search?q=cache:oRGF--ocPgs]:www.gdrc.org/ sustdev/definitions.html+sustainable+develop ment+definition\&cd=2\&hl=sl\&ct=clnk\&gl=siž (Accesed on Ioth June 20I0)

http://www.europeangeoparks.org/isite/ page/8,I,o.asp?mu $=4 \& \mathrm{cmu}=26 \&$ thID $=0 \quad($ Accesed on Ioth June 20I0)

http://www.stat.si/obcinevstevilkah/Vsebina. aspx?id=52\# (Accesed on 8th December 20I0)

Leskovec, I. 2009. Presentation of Idrija through history. In: Book of abstracts. 3rd international Conference "Environmental \& social-economical impact of the $\mathrm{Hg}$ extraction and its use" of the serial nomination "The Mercury + Silver Binomial. Almadén and Idrija with San Luis Potosí. Rudnik živega srebra Idrija, Idrija, Slovenia.

Mohorič, I. I960. Rudnik živega srebra v Idriji, Mestni muzej Idrija, Idrija, Slovenia, $476 \mathrm{pp}$.

Placer, I98I. Geološka zgradba jugozahodne Slovenije (Geologic structure of wouthwestern Slovenia). Geologija 24/I, Geološki zavod Slovenija, Ljubljana, Slovenija, 27-6o. (in Slovenian with English summary)
Placer, I999. Contribution to the macrotectonic subdivision of the border region between Southern Alps and External Dinarides, Geologija 4I (I998), Geološki zavod Slovenije, Ljubljana, Slovenija, 223-255.

Režun, B., Eržen, U. 2004. Idrija’s geological collections - the preservation of natural heritage. Patrimoine de l'industrie No. I2. ICOMOS$\mathrm{TICCIH}$, Paris

Robinson, M., Novelli, M. 2005. Niche tourism: An introduction. In Novelli, M. (ed.) Niche Tourism; contemporary issues, trends and cases, Elsevier Science, Oxford, UK, 27-37.

Stupar, M., Režun, B., Eržen, U. 2005. Strokovne podlage za zavarovanje idrijskega rudišča. In: Razprave poročila, I7. Posvetovanje slovenskih geologov. Oddelek za geologijo, Ljubljana, Slovenia, II6-I2O.

United Nations. 1987. «Report of the World Commission on Environment and Development.« General Assembly Resolution 42/187, II December 1987. Retrieved: 2007-04-I2. Available via http://www.un.org/documents/ga/res/42/ ares42-I87.htm (Accesed on 9th June 2010).

Vrabec, M., Fodor, L. 2006. Late cenozoic tectonics of Slovenia: Structural styles at the NE corner of the Adriatic microplate. In: The Adria microplate: GPS Geolodesy, tectonics and hazards, (NATO Science Series, IV, Earth and environmental Sciences, Vol.6I). Springer, Dorddrecht, I5I-I68.

Zelenc, A. 2007. Klavže: gradivo za pripravo nominacije, Idrija, Slovenia. (unpublished) 